\title{
A Model to Determine Aptitude of Mozambique territory for cultivating and processing Jatropha curcas L. as a bioenergy crop
}

\author{
José Castro Coelho, Pedro Mateus
}

\begin{abstract}
GALP Energia's Biofuels Business Development Unit considered it necessary to create a GIS-based model for identifying and assessing areas to support decision-making on the implementation of Jatropha curcas Linn (JCL) projects in Mozambique. From this need/challenge was born the present methodological proposal for the first prototype of the model. In summary, the identification and subsequent choice of new areas for JCL planting is structured in two phases, which consider: Phase 1 - Macro-scale assessment of the logistics conditions of the sites, from the perspective of the industrial component. This first set of variables includes the qualitative assessment of the following 5 variables: Regional/national connections to the sea port; Local accesses; Electric network; Other support infrastructures; Land availability without DUAT assigned. The appraisal of each of these variables is made according to a scale of four levels of aptitude (High, Moderate, Reduced and Without aptitude), considering their impact on the ease and/or cost of installing and operating industrial units;

Phase 2 - assessment of the agroecological skills of the sites for culture, at the micro scale and from the agronomic perspective. This second set of variables includes the qualitative assessment of the following 7 variables: Climate; Soils; Vegetable Cover; Land availability, ownership and restrictions; Agricultural infrastructure and improvements; Water resources; People and population (availability of man-power). The assessment of each of these variables is made on a four-level fitness scale in view of their impact on the ease and/or cost of setting up and operating JCL plantations.
\end{abstract}

Index Terms - Agroecological Zoning, Bioenergy, Jatropha curcas L., Multicriteria analysis.

\section{INTRODUCTION}

The exponential growth of energy demand worldwide, the depletion of oil reserves and the severe pollutants problems caused by industry that favors greenhouse effect, evidence the need to increase the supply of biofuels production.

According to this, the new energy strategy for Europe from 2011 to 2020 has been discussed in European Union (EU) institutions [1]-[3] This strategy has to be in line with the "Lisbon Treaty" to guide long-term emission-reduction goals, the so-called 20-20-20 . To achieve energy and climate goals,

José Castro Coelho, Department of Sciences and Engineering of Biosystems, School of Agriculture - University of Lisbon, Lisboa, Portugal, Phone No. +351213653177.

Pedro Mateus, Biofuels Development Unit, Galp Energia, Lisboa, Portugal, Phone No. +351 217240407 .

${ }^{1}$ The emission reduction goals, the 20-20-20, are the following: to reduce greenhouse gas emissions by $20 \%$ compared to 1990 levels, to increase the the potential of bioenergy is a key issue. The European Parliament has placed special emphasis on the design of a biomass policy to foment a market for this agricultural and forestry product in order to promote biofuels in Europe. In this regard, the share of biofuel production was up $8 \%$ between 2010 and 2011, reaching 16,027,000 $t$ [4]. Nevertheless, the EU is far from being the major world producer of biofuel [5].

This sets a new overview for studying non-edible oilseeds species for biodiesel production. An alternative is barbados nut or piñon (Jatropha curcas Linn - JCL) crop, perennial bush that is native from Mexico and Central America, grows in most of tropical countries, and it is considered like one of the non-conventional oilseed crops with great expectations for obtaining biodiesel.

The JCL seeds have an outstanding characteristic: their high oil content allows converting it to liquid biofuel, and also the shell can be transformed into biogas and biofertilizers. JCL is a green option to reforest degraded soils and to control erosion, as well as an option to diversify agricultural systems. On the other hand, in several scientific and technical studies [6]-[10] it is reported a wide variation in yields, due lack of study of plant 's genetics, the agronomic handling, as well to the misunderstanding that exists in some countries in the field of zones with best agroecological ability to set the crop. The agroecological zoning (AEZ) refers to a division of land surface and weather into smaller units that have similar characteristics related to its ability, potential yield and environmental impact. However, previous AEZ studies have been conducted with the use of biophysical and ecological datasets to the neglect of equally important socio-economic variables.

In this context, the Portuguese main company of fuel energy (GALP Energia's) and its "Biofuels Business Development Unit" considered it necessary to create a GIS-based model for identifying and assessing areas to support decision-making on the implementation of JCL (agricultural and industrial) projects in Mozambique. From this need/challenge was born the present methodological proposal and the first prototype of the model.

Therefore, this research is conducted at the Mozambique national level to estimate suitable agricultural areas/zones for JCL crop in Mozambique by application of socio-economic variables in conjunction with widely employed biophysical and ecological variables. The objective of this study is to provide an up-to date, GIS based agricultural land suitability

renewable energy share to $20 \%$ of final energy consumption and to increase energy efficiency by $20 \%$. 
assessment for determining suitable agricultural areas/zones for JCL in Mozambique. Biophysical, ecological and socio-economic factors assumed to influence agricultural land use were assembled and the weights of their respective contributions to land suitability for agricultural uses were assessed using analytic hierarchical process. This study used the four levels [highly suitable (3), moderately suitable (2), marginally suitable (1) and unsuitable (0)] suitability classes commonly used by the Food and Agricultural Organization [11]-[12].

\section{THE CONCEPTUAL MODEL AND ITS VARIABLES}

In summary, the identification model and subsequent choice of new areas for JCL planting is structured in two phases, which consider:

- $\quad$ Phase 1 - Macro-scale assessment of the logistics conditions of the areas/zones, from the perspective of the aptitude for implementing an agro-industrial project. This first set of variables includes the qualitative assessment of the following 5 variables: Regional/national connections to the sea port; Local accesses; Electric network; Other support infrastructures; Land availability without DUAT assigned $^{2}$ (Table I).

A complex decision problem is decomposed into its constituent criteria. The criteria are therefore prioritized according to their relative importance within each level. The appraisal of each of these variables is made according to a scale of four levels of aptitude (High, Moderate, Reduced and Without Aptitude), considering its impact on the ease and/or cost of installation and operation of industrial units, which is presented in the following table.

Table I - Macro assessment, first phase (variables and aptitude classes to consider and appreciate)

\begin{tabular}{|c|c|c|c|c|}
\hline \multirow[b]{2}{*}{ Variables } & \multicolumn{4}{|c|}{ Aptitude Classes (score) } \\
\hline & $\begin{array}{c}\text { Without } \\
\text { Aptitude (0) }\end{array}$ & $\begin{array}{c}\text { Reduced } \\
\text { Aptitude (1) }\end{array}$ & $\begin{array}{c}\text { Moderate } \\
\text { Aptitude (2) }\end{array}$ & $\begin{array}{c}\text { High } \\
\text { Aptitude } \\
(3)\end{array}$ \\
\hline $\begin{array}{c}\text { Regional/nati } \\
\text { onal } \\
\text { connections } \\
\text { to the nearest } \\
\text { sea port } \\
\text { (Maputo, } \\
\text { Beira or } \\
\text { Nacala) city } \\
\text { (Maputo, } \\
\text { Xai-Xai, } \\
\text { Inhambane, } \\
\text { Beira, } \\
\text { Chimoio, } \\
\text { Quelimane, } \\
\text { Tete, } \\
\text { Nanpula, } \\
\text { Pemba) }\end{array}$ & $\begin{array}{c}\text { Area/Zone } \\
\text { without } \\
\text { paved roads } \\
\text { and } \\
\text { railways. } \\
\text { Distance to } \\
\text { the nearest } \\
\text { sea port > } \\
250 \mathrm{~km} . \\
\text { Distance to } \\
\text { the nearest } \\
\text { city > } 150 \\
\mathrm{~km}\end{array}$ & $\begin{array}{c}\text { Area/Zone } \\
\text { with remote } \\
\text { connections } \\
(>50 \mathrm{~km}) \text { to } \\
\text { main paved } \\
\text { roads } \\
\text { and/or } \\
\text { railways. } \\
\text { Distance to } \\
\text { the nearest } \\
\text { sea port } \\
250-120 \\
\text { km. } \\
\text { Distance to } \\
\text { the nearest } \\
\text { city } \\
150-100 \mathrm{~km}\end{array}$ & $\begin{array}{c}\begin{array}{c}\text { Areas with } \\
\text { close }\end{array} \\
\text { connections } \\
(<50 \mathrm{~km}) \text { to } \\
\text { main paved } \\
\text { roads } \\
\text { and/or } \\
\text { railways. If } \\
\text { the distance } \\
\text { is more than } \\
\text { 100km, the } \\
\text { existence of } \\
\text { the railway } \\
\text { gains more } \\
\text { relevance. } \\
\text { Distance to } \\
\text { the nearest } \\
\text { sea port } \\
250-120 \\
\text { km. } \\
\text { Distance to } \\
\text { the nearest }\end{array}$ & $\begin{array}{c}\text { Area with } \\
\text { close } \\
\text { connectio } \\
\text { ns }(<50 \\
\mathrm{km}) \text { to } \\
\text { main } \\
\text { national } \\
\text { asphalted } \\
\text { roads } \\
\text { and/or } \\
\text { railway. } \\
\text { Distance } \\
\text { to the } \\
\text { nearest } \\
\text { sea port }< \\
120 \mathrm{~km} . \\
\text { Distance } \\
\text { to the } \\
\text { nearest } \\
\text { city <50 } \\
\text { km }\end{array}$ \\
\hline
\end{tabular}

${ }^{2}$ DUAT - Direito de Uso e Aproveitamento da Terra (right to use and benefit from land)

\begin{tabular}{|c|c|c|c|c|}
\hline & & & $\begin{array}{c}\text { city } 50-100 \\
\mathrm{~km}\end{array}$ & \\
\hline $\begin{array}{c}\text { Local } \\
\text { accesses }\end{array}$ & $\begin{array}{c}\text { Inaccessible } \\
\text { zone }\end{array}$ & $\begin{array}{c}\text { Do not } \\
\text { allow } \\
\text { vehicles } \\
\text { (cars, } \\
\text { tractors, } \\
\text { trucks) to } \\
\text { circulate at } \\
\text { normal } \\
\text { speeds at } \\
\text { any time of } \\
\text { the year }\end{array}$ & $\begin{array}{l}\text { Allow } \\
\text { vehicles } \\
\text { (cars, } \\
\text { tractors, } \\
\text { trucks) to } \\
\text { circulate at } \\
\text { normal } \\
\text { speeds for } \\
\text { much of the } \\
\text { year }\end{array}$ & $\begin{array}{c}\text { Allow the } \\
\text { circulatio } \\
n \text { of } \\
\text { vehicles } \\
\text { (cars, } \\
\text { tractors, } \\
\text { trucks) at } \\
\text { normal } \\
\text { speeds at } \\
\text { any time } \\
\text { of the } \\
\text { year }\end{array}$ \\
\hline $\begin{array}{l}\text { Electric } \\
\text { network }\end{array}$ & $\begin{array}{l}\text { Non-existen } \\
\text { t and very } \\
\text { remote } \\
(>50 \mathrm{~km})\end{array}$ & $\begin{array}{c}\text { Non-existen } \\
\mathrm{t} \text { and remote } \\
(50-20 \mathrm{~km})\end{array}$ & $\begin{array}{c}\text { Not existing } \\
\text { but close } \\
(<20 \mathrm{~km})\end{array}$ & $\begin{array}{l}\text { Already } \\
\text { existing }\end{array}$ \\
\hline $\begin{array}{l}\text { Other support } \\
\text { infrastructure } \\
\mathrm{s}\end{array}$ & $\begin{array}{c}\text { Network of } \\
\text { main } \\
\text { support } \\
\text { services } \\
\text { (workshops } \\
\text {, petrol } \\
\text { stations, } \\
\text { factors of } \\
\text { production, } \\
\text { oil } \\
\text { extraction } \\
\text { factory,....) } \\
\text { very remote } \\
\text { (>50 km) } \\
\text { and } \\
\text { incomplete }\end{array}$ & $\begin{array}{c}\text { Network of } \\
\text { main } \\
\text { support } \\
\text { services } \\
\text { (workshops } \\
\text {, petrol } \\
\text { stations, } \\
\text { factors of } \\
\text { production, } \\
\text { oil } \\
\text { extraction } \\
\text { factory,....) } \\
\text { remote } \\
\text { (50-20 km) } \\
\text { and } \\
\text { incomplete }\end{array}$ & $\begin{array}{c}\text { Main } \\
\text { support } \\
\text { network } \\
\text { (workshops } \\
\text {, petrol } \\
\text { stations, } \\
\text { factors of } \\
\text { production, } \\
\text { oil } \\
\text { extraction } \\
\text { factory,....) } \\
\text { remote } \\
(50-20 \mathrm{~km} \text { ) } \\
\text { or } \\
\text { incomplete }\end{array}$ & $\begin{array}{c}\text { Network } \\
\text { of main } \\
\text { support } \\
\text { services } \\
\text { (worksho } \\
\text { ps, petrol } \\
\text { stations, } \\
\text { factors of } \\
\text { productio } \\
\text { n, oil } \\
\text { extraction } \\
\text { factory,... } \\
\text {.) close } \\
\text { and } \\
\text { complete }\end{array}$ \\
\hline $\begin{array}{c}\text { Land } \\
\text { availability } \\
\text { without } \\
\text { DUAT } \\
\text { assigned }\end{array}$ & $\begin{array}{l}\text { Areas/Zone } \\
\text { s of parks } \\
\text { and natural } \\
\text { and / or } \\
\text { landscape } \\
\text { reserves, } \\
\text { and fragile } \\
\text { areas }\end{array}$ & $\begin{array}{c}\text { Areas/Zone } \\
\text { s of reduced } \\
\text { land } \\
\text { availability } \\
\text { without } \\
\text { DUAT }\end{array}$ & $\begin{array}{c}\text { Areas of } \\
\text { medium } \\
\text { land } \\
\text { availability } \\
\text { without } \\
\text { DUAT }\end{array}$ & $\begin{array}{c}\text { Areas of } \\
\text { high land } \\
\text { availabilit } \\
\text { y without } \\
\text { DUAT }\end{array}$ \\
\hline
\end{tabular}

Phase 2 - assessment of the agroecological skills of the sites for culture, at the micro scale and from the agronomic perspective. This second set of variables includes the qualitative appreciation of the following 7 variables: Climate; Soils; Vegetable Cover; Land availability, ownership and restrictions; Agricultural infrastructure and improvements; Water resources; People and population (availability of man-power). The assessment of each of these variables will be made on a four-level aptitude scale, with a view to their impact on the ease and/or cost of setting up and operating JCL plantations (Table II).

Table II - Micro assessment, second phase (variables and aptitude classes to consider and appreciate)

\begin{tabular}{|c|c|c|c|c|}
\hline \multirow[b]{2}{*}{ Variables } & \multicolumn{4}{|c|}{ Aptitude Classes (score) } \\
\hline & $\begin{array}{c}\text { Without } \\
\text { Aptitude (0) }\end{array}$ & $\begin{array}{c}\text { Reduced } \\
\text { Aptitude (1) }\end{array}$ & $\begin{array}{c}\text { Moderate } \\
\text { Aptitude (2) }\end{array}$ & $\begin{array}{c}\text { High } \\
\text { Aptitude } \\
\text { (3) }\end{array}$ \\
\hline Climate & $\begin{array}{l}\text { All the others } \\
\text { Climate types }\end{array}$ & $\begin{array}{l}\text { Steppe } \\
\text { semi-arid } \\
\text { climate } \\
\text { (Bs). } \\
\text { Marked } \\
\text { water } \\
\text { deficiency } \\
\text { (4-6 dry } \\
\text { months), }\end{array}$ & $\begin{array}{l}\text { Rainy } \\
\text { tropical } \\
\text { savanna } \\
\text { climate } \\
\text { (Aw). } \\
\text { Moderate } \\
\text { water } \\
\text { deficiency } \\
\text { (3-4 dry }\end{array}$ & $\begin{array}{l}\text { Tropical } \\
\text { monsoon } \\
\text { (Am) and } \\
\text { altitude } \\
\text { (Cw) } \\
\text { climates. } \\
\text { Water } \\
\text { deficienci } \\
\text { es are low }\end{array}$ \\
\hline
\end{tabular}


International Journal of Engineering and Applied Sciences (IJEAS)

ISSN: 2394-3661, Volume-7, Issue-4, April 2020

\begin{tabular}{|c|c|c|c|c|}
\hline & & $\begin{array}{l}\text { very intense } \\
\text { and } \\
\text { frequent } \\
\text { droughts, } \\
\text { annual } \mathrm{R}< \\
600 \mathrm{~mm} \text {, } \\
\text { annual } \mathrm{T}< \\
22^{\circ} \mathrm{C}\end{array}$ & $\begin{array}{l}\text { months: } \\
\mathrm{R}<60 \mathrm{~mm}) \\
\text { annual } \mathrm{R} \\
600-1000 \\
\mathrm{~mm} \text {, annual } \\
\mathrm{T} \\
22^{\circ} \mathrm{C}-26^{\circ} \mathrm{C}\end{array}$ & $\begin{array}{l}\text { (1-3 dry } \\
\text { months), } \\
\text { annual } \\
\mathrm{R}>1000 \\
\mathrm{~mm}, \\
\text { annual T } \\
>26^{\circ} \mathrm{C}\end{array}$ \\
\hline Soils & $\begin{array}{l}\text { Soils with } \\
\text { prolonged } \\
\text { flooding or } \\
\text { flooding } \\
\text { periods and } \\
\text { very low } \\
\text { fertility }\end{array}$ & $\begin{array}{l}\text { Heavy soils } \\
\text { without } \\
\text { prolonged } \\
\text { flooding / } \\
\text { flooding } \\
\text { periods and } \\
\text { low fertility }\end{array}$ & $\begin{array}{l}\text { Sandy soils } \\
\text { with poor } \\
\text { fertility and } \\
\text { low water } \\
\text { storage } \\
\text { capacity } \\
\text { and } \\
\text { moderate } \\
\text { fertility }\end{array}$ & $\begin{array}{l}\text { Frank } \\
\text { soils with } \\
\text { good } \\
\text { fertility } \\
\text { and } \\
\text { medium } \\
\text { to high } \\
\text { water } \\
\text { storage } \\
\text { capacity } \\
\text { and high } \\
\text { fertility }\end{array}$ \\
\hline $\begin{array}{l}\text { Vegetabl } \\
\text { e cover }\end{array}$ & $\begin{array}{l}\text { Very dense } \\
\text { and dense } \\
\text { forest }\end{array}$ & $\begin{array}{l}\text { Dense } \\
\text { tree/shrub } \\
\text { forest } \\
\text { and/or } \\
\text { sparse } \\
\text { forest. } \\
\text { Requiring } \\
\text { intense } \\
\text { selective } \\
\text { deforestatio } \\
\mathrm{n}\end{array}$ & $\begin{array}{l}\text { Grass and } \\
\text { bush } \\
\text { savanna. } \\
\text { Requiring } \\
\text { removal of } \\
\text { shrubs and } \\
\text { heavy } \\
\text { harrowing } \\
\text { for soil } \\
\text { regularizati } \\
\text { on }\end{array}$ & $\begin{array}{l}\text { Clean of } \\
\text { vegetatio } \\
\text { n. Only } \\
\text { requiring } \\
\text { simple } \\
\text { disc } \\
\text { harrow }\end{array}$ \\
\hline $\begin{array}{l}\text { Land } \\
\text { availabilit } \\
\mathrm{y}, \\
\text { ownershi } \\
\mathrm{p} \text { and } \\
\text { restriction } \\
\mathrm{s}\end{array}$ & $\begin{array}{l}\text { Land with } \\
\text { very good } \\
\text { agricultural } \\
\text { aptitude. Use } \\
\text { for food crops }\end{array}$ & $\begin{array}{l}\text { Reduced } \\
\text { availability } \\
\text { (spot within } \\
\text { a circle of } \\
\text { radius of } \\
15 / 20 \mathrm{~km} \\
\text { and with <5 } \\
\text { to } 8,000 \mathrm{ha} \text { ) } \\
\text { and/or } \\
\text { reduced } \\
\text { ownership } \\
\text { (20-25 } \\
\text { years) } \\
\text { and/or with } \\
\text { doubts } \\
\text { about the } \\
\text { possibility } \\
\text { of using it } \\
\text { for JCL }\end{array}$ & $\begin{array}{l}\text { Moderate } \\
\text { availability } \\
(15,000 \text { to } \\
25,000 \\
\text { hectares } \\
\text { within the } \\
\text { ideal circle) } \\
\text { and/or } \\
\text { average } \\
\text { ownership } \\
\text { (25-35 } \\
\text { years) and } \\
\text { without any } \\
\text { restrictions } \\
\text { on use }\end{array}$ & $\begin{array}{l}\text { Abundant } \\
\text { availabilit } \\
\text { y (> } \\
25,000 \\
\text { hectares } \\
\text { within an } \\
\text { ideal } \\
\text { circle), } \\
\text { lasting } \\
\text { tenure (> } \\
35 \text { years) } \\
\text { and } \\
\text { without } \\
\text { any } \\
\text { restriction } \\
\text { s on use }\end{array}$ \\
\hline $\begin{array}{l}\text { Agricultu } \\
\text { ral } \\
\text { infrastruc } \\
\text { ture and } \\
\text { improve } \\
\text { ments }\end{array}$ & $\begin{array}{l}\text { Absence of } \\
\text { infrastructure } \\
\text { and } \\
\text { agricultural } \\
\text { improvements } \\
\text {. Without } \\
\text { "people" and } \\
\text { without } \\
\text { agricultural } \\
\text { "past" }\end{array}$ & $\begin{array}{l}\text { Absence of } \\
\text { infrastructu } \\
\text { re and } \\
\text { agricultural } \\
\text { improveme } \\
\text { nts. With } \\
\text { "people" } \\
\text { and } \\
\text { agricultural } \\
\text { "past" }\end{array}$ & $\begin{array}{l}\text { Existence of } \\
\text { a more or } \\
\text { less } \\
\text { operational } \\
\text { agricultural } \\
\text { infrastructu } \\
\text { re, with } \\
\text { "people" } \\
\text { and "past", } \\
\text { or even with } \\
\text { some } \\
\text { activity } \\
\text { already } \\
\text { started }\end{array}$ & $\begin{array}{l}\text { Existence } \\
\text { of a good } \\
\text { operation } \\
\text { al } \\
\text { agricultur } \\
\text { al } \\
\text { infrastruc } \\
\text { ture, with } \\
\text { "people", } \\
\text { "past" } \\
\text { and } \\
\text { activity }\end{array}$ \\
\hline $\begin{array}{l}\text { Water } \\
\text { resources }\end{array}$ & $\begin{array}{l}\text { Absence of } \\
\text { surface (rivers } \\
\text { and dams) and } \\
\text { ground water }\end{array}$ & $\begin{array}{l}\text { Absence of } \\
\text { surface } \\
\text { water } \\
\text { (rivers and } \\
\text { dams). } \\
\text { Presence of } \\
\text { ground } \\
\text { water, need } \\
\text { to drill } \\
\text { holes and } \\
\text { pumping. }\end{array}$ & $\begin{array}{l}\text { Surface } \\
\text { waters } \\
\text { (rivers and } \\
\text { dams) } \\
\text { existing but } \\
\text { not } \\
\text { functional } \\
\text { throughout } \\
\text { the year. } \\
\text { Need to } \\
\text { carry out } \\
\text { works / }\end{array}$ & $\begin{array}{l}\text { Surface } \\
\text { water } \\
\text { (rivers } \\
\text { and } \\
\text { dams) } \\
\text { abundant, } \\
\text { which } \\
\text { never dry, } \\
\text { and easy } \\
\text { and } \\
\text { immediat } \\
\text { e }\end{array}$ \\
\hline
\end{tabular}

\begin{tabular}{|c|c|c|c|c|}
\hline & & & $\begin{array}{l}\text { improveme } \\
\text { nts }\end{array}$ & $\begin{array}{l}\text { capture/p } \\
\text { umping. }\end{array}$ \\
\hline $\begin{array}{l}\text { People } \\
\text { and } \\
\text { Populatio } \\
\text { n }\end{array}$ & $\begin{array}{l}\text { Area without } \\
\text { or with very } \\
\text { low } \\
\text { population } \\
\text { density }(<10 \\
\left.\text { people } / \mathrm{km}^{2}\right) \text { in } \\
\text { the vicinity }\end{array}$ & $\begin{array}{l}\text { Area with } \\
\text { low and / or } \\
\text { high } \\
\text { population } \\
\text { density, and } \\
\text { / or } \\
\text { relatively } \\
\text { dispersed, } \\
\text { and / or } \\
\text { unbalanced } \\
\text { age } \\
\text { pyramid, } \\
\text { and / or } \\
\text { people } \\
\text { without } \\
\text { work habits } \\
\text { and } \\
\text { agricultural } \\
\text { and / or } \\
\text { industrial } \\
\text { training }\end{array}$ & $\begin{array}{l}\text { Area with } \\
\text { average } \\
\text { population } \\
\text { density but } \\
\text { relatively } \\
\text { dispersed, } \\
\text { and / or } \\
\text { unbalanced } \\
\text { age } \\
\text { pyramid, } \\
\text { and / or } \\
\text { people } \\
\text { without } \\
\text { work habits } \\
\text { and } \\
\text { agricultural } \\
\text { and / or } \\
\text { industrial } \\
\text { training }\end{array}$ & $\begin{array}{l}\text { Area with } \\
\text { medium } \\
\text { and } \\
\text { relatively } \\
\text { concentra } \\
\text { ted } \\
\text { populatio } \\
\text { n density, } \\
\text { balanced } \\
\text { age } \\
\text { pyramid, } \\
\text { people } \\
\text { with } \\
\text { work } \\
\text { habits } \\
\text { and } \\
\text { agricultur } \\
\text { al and / or } \\
\text { industrial } \\
\text { training }\end{array}$ \\
\hline
\end{tabular}

\section{THE GIS PLATFORM}

The proposed model has a markedly spatial use where the main objective is the geographical characterization of the aptitude for the implantation of an agro-industrial project of JCL in Mozambique. The expected end result is a thematic map of Mozambique classified by four aptitude classes: high, moderate, reduced and without aptitude (which means exclusion of the area).

The tool used for cartography elaboration was ArcMap GIS Software, which consists of computer mapping system that relates locations with agroclimatic, social, infrastructures/logistic, etc., information equal, in this case, to Jatropha curcas crop and industrial project requirements.

One way to implement the model in a GIS framework is to construct a cartographic model consisting of a collection of maps recorded on a common cartographic basis, where each map refers/retracts to a variable and on which mathematical operations can be performed. The common cartographic base is an indispensable requirement to ensure that any point (coordinate) has exactly the same geographical location on all maps. The cartographic basis that we have used came from [13]-[15].

Maps are raster in shape, meaning that a grid where the pixel is the base processing unit and defines the accuracy of the map defines space. Performing algebraic operations on one or more maps at the same time is called map algebra. With map algebra, it is possible to establish a set of mathematical functions that allow processing the various maps contained in the GIS cartographic base.

Designing scenarios that represent different alternatives and points of view on how best to characterize fitness is achieved with multicriteria analysis. Multicriteria analysis consists of assigning different weights to the model variables so that the addition of the variables reflects their importance. It can be done by percentages, weighted average, and other methods, but the central idea is that the user/modeller has the ability to differentiate variables by their importance as well as perform sensitivity analyses on variables. 
The following Fig.1 is an exemplary scheme of the calculation procedure from variables to final scenarios using the GIS structure and multicriteria analysis.

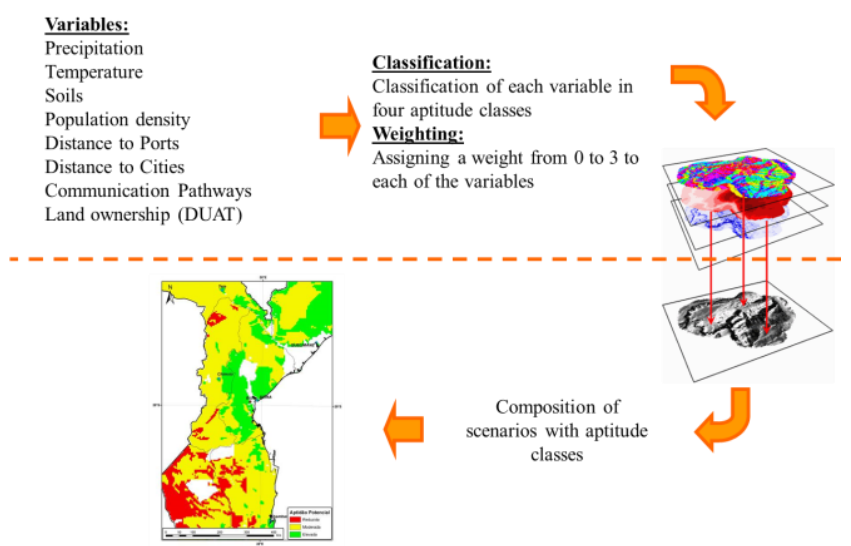

Fig. 1 - Steps of applying the model in a GIS framework to obtain aptitude class maps

\section{Classification and appreciation of the base variables}

The proposed conceptual model presents two sets of variables for macro and micro evaluation. Some of these variables are easily mapped because information already exists or is directly derived from existing data (eg precipitation, seaport links, roads and railways, etc.) while other variables are more difficult to map because no information is available and/or because they require field work (eg agricultural infrastructure and improvements, electricity grid, etc.).

The first step in building the GIS database is to define which variables will give rise to maps. This step is closely linked to the ability to obtain relevant information from a variety of sources.

To create a first approximation to the case study of Mozambique, we were able to obtain cartographic information for the following variables: precipitation, temperature, pedological resources, population density, distance to ports, distance to cities, roads, railways and land tenure.

Therefore, and although this list includes variables that we previously considered in the conceptual model to belong to the 1 st and 2 nd evaluation phases, we will consider them, from this point on, as the basic variables for obtaining aptitude maps at macro, or national scale.

\section{Construction of maps with valuation of base variables}

After defining the base variables, it is necessary to digitize and construct the maps, in this case in raster format. There is no general rule for this, and in each case, the solution adopted depends on the type and detail of the information available.

The base variable maps were obtained by:

Precipitation - digitizing a map [13] with a scale of 1:12,000,000;

Temperature - digitization of a map [13] with a scale of - 1:12,000,000;

Pedological features - digitizing a map [13] with a scale of - 1:6,000,000;
Population density - digitization of a map [13] with a scale of - 1:6,000,000;

Distance to ports - buffer analysis based on seaport location [13];

Distance to cities - spatial analysis (buffer) based on city location [14]

Communication routes - Spatial analysis (buffer) based on the road and rail network [14];

Land title - digitalization of two maps: one with location of areas occupied by reserves and natural parks2; and another with localization of areas without DUAT assigned [15].

Sorting is a simple task of reclassifying previously obtained maps by directly assigning each pixel a score based on the following closed scale (Table III).

Table III - Aptitude weighs and classes

\begin{tabular}{|c|c|}
\hline Weighs & Aptitude classes \\
\hline 0 & Without Aptitude \\
\hline 1 & Reduced Aptitude \\
\hline 2 & Moderate Aptitude \\
\hline 3 & High Aptitude \\
\hline
\end{tabular}

We emphasize the fact that the base variable maps may not include the "without-aptitude" class, because the origin and/or nature of the information for the definition of this class may not be represented there. For example, the soil variable map contains the georeferenced information of soils and their characteristics, but by itself does not tell us enough about the occurrence and intensity of soaking problems in a given location - which is a condition of exclusion of this site for the cultivation of JCL - as it may be related to the topography of the land and/or the hydrographic network. It makes no sense, therefore, to include in the same map two sources of information with different characteristics (e.g. soil and topography), and it is preferable to make this correction only at the end of the calculations.

\section{Multicriteria Analysis}

As mentioned, multicriteria analysis is a way of creating scenarios by assigning weights to variables. The method used in this case study was the weighted average, where the user uses the following closed weight scale (Table IV).

Table IV - Relevance weighs and classes

\begin{tabular}{|c|c|}
\hline Weighs & Relevance classes \\
\hline 0 & Not relevant at all \\
\hline 0.5 & Little relevance \\
\hline 1 & Relevant \\
\hline 1.5 & High relevance \\
\hline 2 & Very high relevance \\
\hline
\end{tabular}

This scale makes it easy to identify, according to the user's perception, which variables are most relevant for the construction of a given scenario. It is a simple scale that aims to give the user the ability to, in the extreme, neglect or duplicate the effect of a given variable.

The baseline or general suitability/aptitude scenario was constructed by assigning weight 1 to all variables, and reflects 
International Journal of Engineering and Applied Sciences (IJEAS)

ISSN: 2394-3661, Volume-7, Issue-4, April 2020

the equal importance given to all variables. Alternative or specific suitability scenarios are obtained by applying an algebraic equation that will calculate the weighted average resulting from the weights assigned in the multicriteria analysis.

If we consider the following weighting scenario as an example Table V).

Table V - Variables and weighs of a hypothetic scenario

\begin{tabular}{|c|c|}
\hline Variables & weight \\
\hline Precipitation [Pre] & 1.5 \\
\hline Temperature [Temp] & 0.5 \\
\hline Soil Resources[SR] & 1.0 \\
\hline Population Density [PopD] & 2.0 \\
\hline Distance to Ports [DPort] & 2.0 \\
\hline Distance to City [DC] & 2.0 \\
\hline Communication Ways [CW] & 1.0 \\
\hline Land Wonership [LW] & 0.0 \\
\hline Total & 10.0 \\
\hline
\end{tabular}

We get the following weighted average equation:

weighted average $=(1.5 \times$ Pre $+0.5 \times$ Temp $+S R+2.0 \times P o p D+$ $2.0 \times$ D Dort $+2.0 \times D C+C W) / 10.0$

which will be applied to each pixel.

In the end, we will get a map where each pixel is scored between 0 and 3, which corresponds to its aptitude class.

In correcting the scenario maps, we removed the excluded areas (without aptitude) and reclassified the map legend from initial quantitative value, between 0 and 3, to a qualitative value of aptitude class (low, moderate, high). It is more versatile to remove exclusion areas in the end because it avoids recalculating the scenario when identifying new areas.

After the correction, we obtained the final maps of the macro location scenarios that will support the decision on which regions of interest for the implementation of agro-industrial bioenergy projects. Once the target regions are identified and classified at the macro scale, the next step will be to identify and classify the variables of the second phase of the model that require additional and detailed field work of micro localization.

\section{THE FIRST OUTPUTS OF THE MODEL}

As we have said before, the sought and expected end result of each "run" of the model is a thematic map of Mozambique classified by four skill levels: high, moderate, low and no aptitude/exclusion.

To rehearse the model we decided to build and run the following 3 scenarios (table VI).

Table VI - Variables and weighs of the three studied scenarios

\begin{tabular}{|c|c|c|c|}
\hline Variables & $\begin{array}{c}\text { Scenario } \\
\mathbf{1}\end{array}$ & $\begin{array}{c}\text { Scenario } \\
\mathbf{2}\end{array}$ & $\begin{array}{c}\text { Scenario } \\
\mathbf{3}\end{array}$ \\
\hline Precipitation $[$ Pre $]$ & 1,0 & 0,0 & 1,0 \\
\hline $\begin{array}{c}\text { Temperature } \\
{[\text { Temp] }}\end{array}$ & 1,0 & 0,0 & 1,0 \\
\hline Soil Resources[SR] & 1,0 & 0,0 & 1,0 \\
\hline Population Density & 0,0 & 1,0 & 1,0 \\
\hline
\end{tabular}

\begin{tabular}{|c|c|c|c|}
\hline$[$ PopD] & & & \\
\hline $\begin{array}{c}\text { Distance to Ports } \\
{[\text { DPort }]}\end{array}$ & 0,0 & 1,0 & 1,0 \\
\hline $\begin{array}{c}\text { Distance to City } \\
{[D C]}\end{array}$ & 0,0 & 1,0 & 1,0 \\
\hline $\begin{array}{c}\text { Communication } \\
\text { Ways }[C W]\end{array}$ & 0,0 & 1,0 & 1,0 \\
\hline $\begin{array}{c}\text { Land Wonership } \\
{[L W]}\end{array}$ & 0,0 & 1,0 & 1,0 \\
\hline
\end{tabular}

The first two scenarios give us a partial view of the territory's ability to implement the Jatropha project: Scenario 1 refers to soil and climate conditions and Scenario 2 refers to logistics conditions. Scenario 3, which we may call the general scenario, considers all 8 variables and gives them equal weight or importance.

The following Fig 2, 3 and 4 show the final maps for the three scenarios.

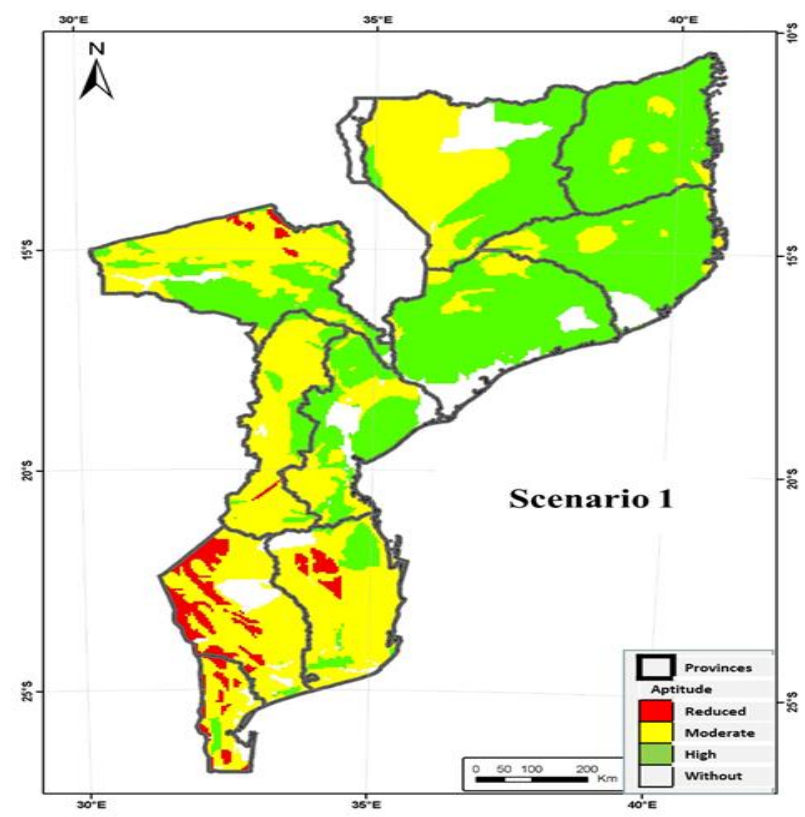

Figure 2 - Scenario1 map (pedoclimatic variables)

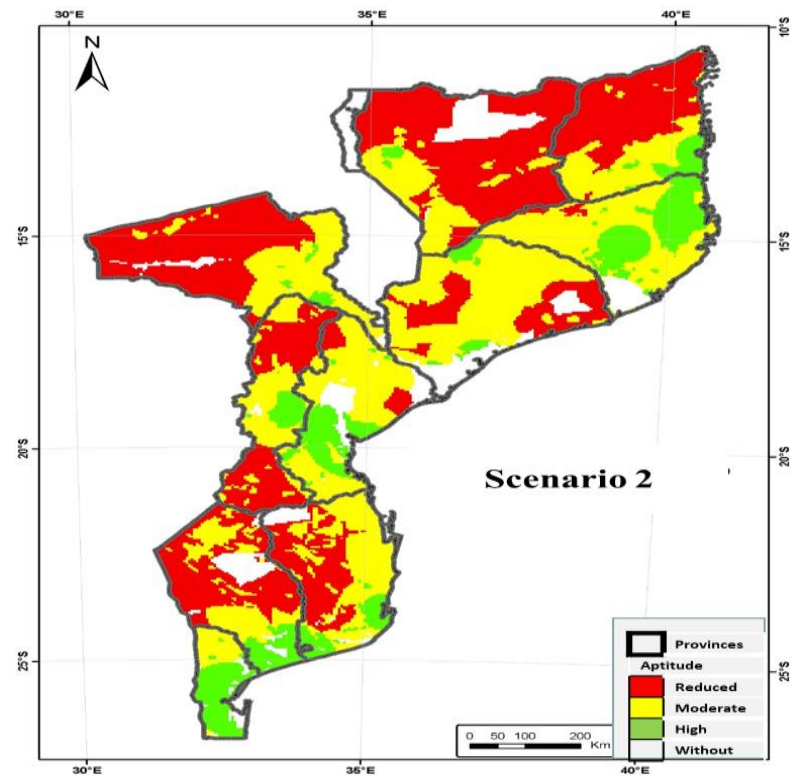

Figure 3 - Scenario 2 map (social and logistics variables) 


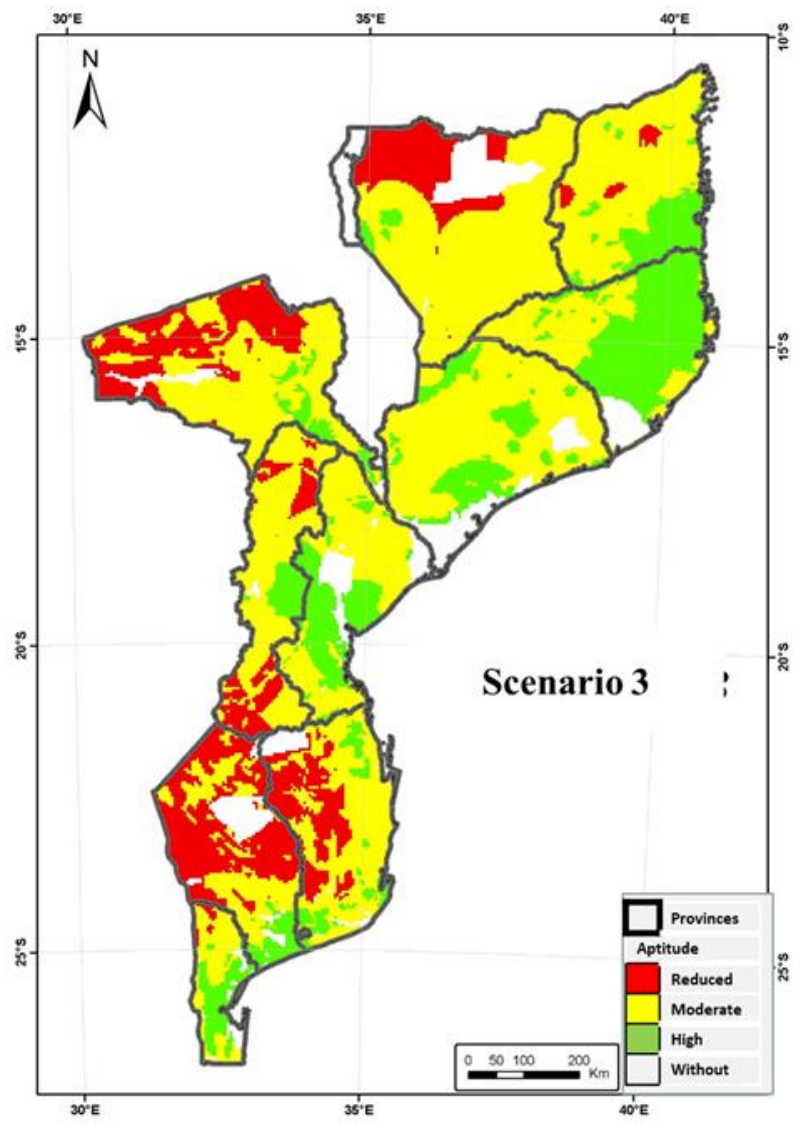

Figure 4 - Scenario3 map (all variables)

\section{CONCLUSION}

The model proved to be easy, robust and useful to use. However, the scenarios tested lack the adjustment of the weights of importance to be attributed to the various variables. A practical and appropriate way to achieve this would be to form a group of experts and ask each one to assign a score/class of importance to each variable, in order to obtain a weighted average score for each one.

\section{REFERENCES}

[1] European Commission (2010). Energy 2020: A Strategy for Competitive, Sustainable and Secure Energy. COM (2010) 639 final, Brussels.

[2] European Commission (2011). Recent Progress in Developing Renewable Energy Sources and Technical Evaluation of the Use of Biofuels and Other Renewable Fuels in Transport in Accordance with Article 3 of Directive 2001/77/EC and Article 4(2) of Directive 2003/30/EC. SEC(2011) 130 Final, Brussels.

[3] European Parliament (2010). A new Energy Strategy for Europe 2011-2020. P7_TA(2010)0441, Brussels.

[4] Eurostat (2012). https://ec.europa.eu/eurostat

[5] Demirbas, A., 2009. Political, economic and environmental impacts of biofuels: a review. Applied Energy 86, 108-117.

[6] Heller, Joachim (1996). Physic nut. Jatropha curcas L. Promoting the conservation and use of underutilized and neglected crops. 1. Institute of Plant Genetics and Cr op Plant Research, Gatersleben/ International Plant Genetic Resources Institute, Rome. 66 pp. ISBN 92-9043-278-0.

[7] FACT FOUNDATION (2006). Jatropha Handbook. First Draft. March 2006. 45 pp. www. fact-fuels.org.

[8] Jongschaap, R.E.E.; Corré, W.J., Bindraban, P.S. and Brandenburg, W.A. (2007). Claims and Facts on Jatropha curcas L. Global Jatropha curcas evaluation, breeding and propagation programme. Plant Research International B.V., Wageningen. 66 pp.

[9] WRC (2007). Jatropha curcas in South Africa: An Assessment of its Water Use and Bio-Physical Potential. Edited by MA Holl, MB Gush, J
Hallowes and DB Versfeld. November 2007. 154 pp. WRC Report No 1497/1/07. ISBN 978-1-77005-593-3.

[10] KnowGenix (2008). Best Practices for Long-Term Jatropha Development. July 2008, 14 pp. www.futureenergyevents.com/jatropha.

[11] FAO (1976). A framework for land evaluation (Soils Bulletin No. 32) Rome: Food and Agriculture Organization of the United Nations.

[12] FAO (2012). Natural Resources Assessment for Crop and Land Suitability: An Application for selected bioenergy crops in Southern Africa region. Integrated Crop Management, 14: ISBN 978-92-5-107218-9

[13] MINED (1986). Atlas Geográfico de Moçambique, Ministério da Educação e Cultura de Moçambique.

[14] CENACARTA (2007). Centro Nacional de Cartografia e Teledetecção / National Cartography \& Remote Sensing [http://www.cenacarta.com/]

[15] CEPAGRI (2007). Centro de Promoção da Agricultura (CEPAGRI), Moçambique [http://www.cepagri.gov.mz/]

\section{First Author}

Education:

Aggregation - Agronomy Institute of Lisbon (ISA) - Technical University of Lisbon (classification: Approved by unanimous decision), 2006.

MBA - Managerial Sciences Institute of Lisbon (ISCTE) - Marketing specialization (classification: 15/20), 1993-1994.

Ph.D. - Agronomy Institute of Lisbon (ISA) - Agronomy (classification: Distinction and Honor by unanimous decision), 1989 -1993.

MSc. - Agronomy Institute of Lisbon (ISA) - Plant Production (classification: 18/20), 1985-1987.

Agronomy Eng.: Agronomy Institute of Lisbon (ISA) - specialization in agricultural economics (classification: 15/20), 1977-1983.

Membership of professional bodies:

- Portuguese Engineers Order (OE);

- $\quad$ Portuguese Society of Agrarian Sciences (SCAP);

- Portuguese Association of Agricultural Economists (APDEA);

- Tropical Studies Center for Development (CENTROP)

\section{Second Author}

Education:

Postgraduate Diploma - Lisbon School of Economics \& Management (ISEG) - Management Control and Business Finance (classification: 17/20), 2014.

MSc - Instituto Superior Técnico (IST) - Hydraulics and Water Resources (classification: 5/5), 2005-2008.

Agronomy Eng.: Agronomy Institute of Lisbon (ISA) - Rural Engineering (classification: 14/20), 1997-2004. 